
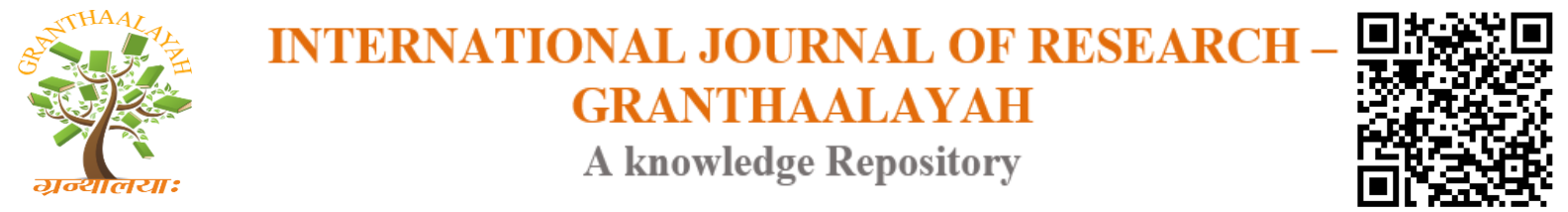

Science

\title{
STUDY OF NUTRITIONAL CONSTITUENTS AND SENSORY EVALUATION OF BAKERY PRODUCTS PREPARED FROM SEED AND BARK OF PRUNUS PERSICA (PEACH)
}

\author{
Neha Qumar ${ }^{* 1}$ \\ ${ }^{*}$ Lecturer, Pushp Institute of Sciences and Higher Studies, INDIA
}

DOI: https://doi.org/10.29121/granthaalayah.v4.i6.2016.2632

\section{ABSTRACT}

Medicinal plants are local heritage with global importance. Prunus persica Seeds and Bark are used as traditional medicine for treatment of blood diseases, anemia rheumatism jaundice, antioxidant and anti-inflammatory agent. So the present study was planned for analysed the nutritional constituents of Prunus persica Seeds and Bark such as Moisture, Protein, fat and ash were analyzed using AOAC methods. Carbohydrate content of the sample was estimated by Difference method. The research was designed to investigate proximate composition. The results of proximate analysis indicated that seeds and bark had appreciable amounts of Protein (2.2\% and 1.0\%), Carbohydrate (50.3\% and 58.7\%) and fat (36.9\% and 29.2\%) on dry basis with observed no significant difference $(P \leq 0.05)$. Acceptability evaluation of prepared recopies was performed by semi trained panel through 9 point Hedonic rating scale test. The result revealed that among the recipes (Biscuits and Baked bite) prepared by adding $2 \%, 4 \%$, $6 \%$ and $8 \%$ Powder of Seed and Bark that variant 1, 2 and 3 were acceptable when comparable to standard recipe. There is no significance difference $(P \leq 0.005)$ when they were tested statistically. Considering the pharmaceutical action of Seeds and Bark for treatment of many diseases and that the reasonably safe to use, its development is important for the pharmaceutical industries. This study generated base line information about the peach Seeds and Bark which will be beneficial to treat various diseases. This study also indicates that both Seeds and Bark can be valuable in generating awareness among people to control various diseases and to improve their nutrition and health status.

Keywords:

Anti- inflammatory, antioxidant Prunus persica, Pharmaceutical, rheumatism.

Cite This Article: Neha Qumar, "STUDY OF NUTRITIONAL CONSTITUENTS AND SENSORY EVALUATION OF BAKERY PRODUCTS PREPARED FROM SEED AND BARK OF PRUNUS PERSICA (PEACH)" International Journal of Research - Granthaalayah, Vol. 4, No. 6 (2016): 12-24. 


\section{INTRODUCTION}

Over the last few years researches have aimed at identifying and validating plant derived substances for treatment of various diseases. Interestingly, it is estimated that more than $25 \%$ of modern medicines are directly or indirectly derived from plant. In the context, it is worth mentioning that Indian medicinal plants are considered vast sources of several pharmacologically active principles and compounds and that are commonly used in home remedies against multiple ailment [1]. The medicinal plants are useful for healing as well as for curing of human diseases because of the presence of phytochemical constituents [2].

Prunus persica (Aaru) belongs to the family Rosaceae is a deciduous tree up to $10 \mathrm{~m}$. high. Commonly cultivated for edible fruits from sub-Himalayan region up to $2400 \mathrm{~m}$ [3]. Plum (Prunus domestica L.) and peach (Prunus persica L.), from the family Rosaceae, are one of the most widely consumed fruits during the summer season. The fruits, with somewhat sour and astringent taste, are low in caloric content but have high nutritive value. They contain natural sugars (sucrose, glucose and fructose), organic acids (citric acid and malic acid), fiber (pectin), tannins, and no saturated fat [4].

Nonetheless they are packed with numerous health promoting compounds, mineral and vitamins. These are moderate source of antioxidant, vitamin $\mathrm{C}$. vitamin $\mathrm{C}$ have anti-oxidant effects and is required for connective tissue synthesis in the body. They are rich in many vital minerals such as Potassium, Fluoride and iron. They also contain health promting Flavonoids, poly phenolic antioxidants [5].

The fruit is used as a demulcent, an anti-scorbutic and a stomachic. Fruit being aphrodisiac, antipyretic, act as a tonic to the brain, enhance the blood, removes bad smell from the mouth. [6].

The seeds are used as an anthelmintic and emmenagogue.The oil extracted from seeds is known as "kapha", used as an abortifacient, good in deafness, piles, stomach troubles of children and earache. Peach kernels are used for blood diseases, menstrual disorders, coughs and rheumatism in China and Malaya [7]. The kernel oil is applied to impetigo. The bark isused in leprosy and jaundice [8].

The seed contains 'laetrile', a substance also called vitamin B17. Leaves of P. persica have been investigated for their antioxidant [9] and anti-inflammatory [10] activities in the past.However, its detail biological activities are hitherto unreported. Therefore, the present study was undertakento evaluate the biological activities spectrum of P.persica [11].

The seed and bark are used in medicines. It is also used as a laxatives, depuratives, antiseptic, for treatment of rheumatism, against cough and haemorrhages. Furthermore, they have been used to treat high blood pressure, blood disease, colic and anemia. The inner white bark of the root is used as a prophylactic in epidemics and remedy for dropsy and jaundice. It is quieting and insecticide. Prunus persica extract may be useful for protection against UV- induced skin sdamage when topically applied [12]. 
The chemical constituents of the herb include the cyanogenic glycosides, amygdalin and prunasin [13] as major components along with glycerides, sterols, and emulsion. Recently, glycosides from this plant seeds have been reported for the anti-tumor activity promoting Epstein-Bar virus activity in early antigen-infected lymphoblastoid cells. Amygdalin is also abundant in the seeds of bitter almond and apricots of the Prunus genus, and other rosaceous plants [14].

Amygdalin extracted from Persicae semen was studied for anticancer activity. An alkaloid persicaside with anti inflammatory activity was isolated from its seeds.

\section{ORIGIN AND CULTIVATION}

The peach, Prunus persica, is a deciduous tree, native to North-West China, in the region comprised between the Tarim basin and the north slopes of the Kunlun Shan Mountains, where it was first domesticated and cultivated. It bears an edible juicy fruit also called a peach [15]. The species name persica refers to its widespread cultivation in Persia, whence it was transplanted to Europe. It belongs to the genus Prunus which includes the cherry and plum, in the family Rosaceae. The peach is classified with the almond in the subgenus Amygdalus, distinguished from the other subgenera by the corrugated seed shell. Peaches and nectarines are the same species, even though they are regarded commercially as different fruits [16]. Nectarines have an orange center and faint fuzz, while peaches have white centers and very fuzzy skin; genetic studies suggest nectarines are produced due to a recessive allele, whereas peaches are produced from dominant allele for fuzzy skin.

Prunus persica grows to 4-10 $\mathrm{m}(13-33 \mathrm{ft})$ tall and 6 in. in diameter. The leaves are lanceolate, $7-16 \mathrm{~cm}$ (2.8-6.3 in) long, $2-3 \mathrm{~cm}(0.79-1.2 \mathrm{in})$ broad, pinnately veined. The flowers are produced in early spring before the leaves; they are solitary or paired, $2.5-3 \mathrm{~cm}$ diameter, pink, with five petals. The fruit has yellow or whitish flesh, a delicate aroma, and a skin that is either velvety (peaches) or smooth (nectarines) in different cultivars (Cellular Methods in Biology). The flesh is very delicate and easily bruised in some cultivars, but is fairly firm in some commercial varieties, especially when green. The single, large seed is red-brown, oval shaped, approximately $1.3-2 \mathrm{~cm}$ long, and is surrounded by a wood-like husk. Peaches, along with cherries, plums and apricots, are stone fruits (drupes). There are various heirloom varieties, including the Indian peach, which arrives in the latter part of the summer [17].

P. persica L. Batch (Peach) named as Amygdalus persica is a deciduous tree of the subfamily Prunoideae of the family Rosaceae with a height of 5 to $10 \mathrm{~m}$ and is commonly cultivated in West Asia, Europe, Himalayas and India up to an altitude of $1000 \mathrm{ft}$. There are about 100 genera and 3,000 species in Rosaceae family. Prunus has nearly 200 species cultivated for their edible fruits and seeds [18]. 


\section{MATERIAL AND METHODS}

\section{COLLECTION AND PREPARATION OF RAW MATERIAL}

The study was done on the Seeds and Bark of Prunus persica to popularize their usage as an medicinal herbs which are useful for patients suffering from diseases and ailments, like diabetes, menstrual disorder, blood diseases, cough, wound healing etc. Prusus persica extracts and active metabolities possess several types of activities such as antibacterial, antifungal, antioxidant and antiviral, etc. The peach Seed and Bark were collected from Pilibhit (U.P) then dried the seed and made the powder which was used during the experiment.

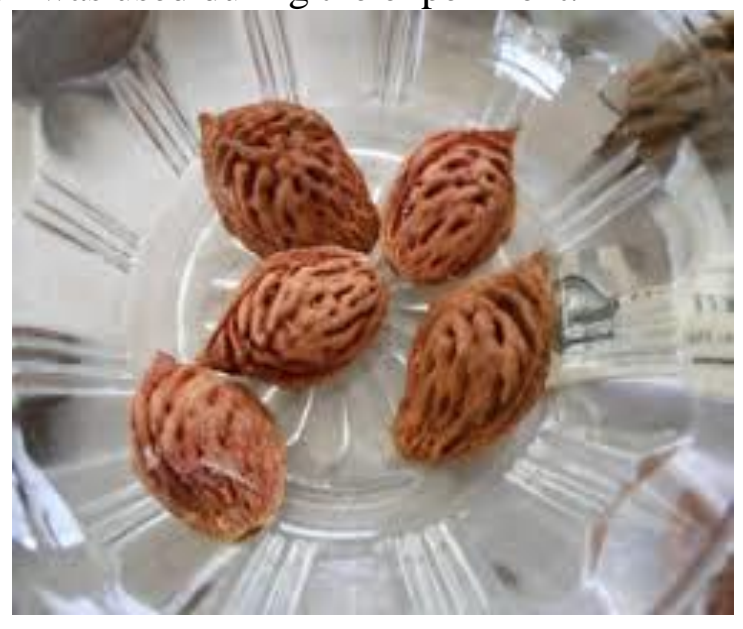

\section{Peach (Prunus persica)}

The whole methodology was divided into three phase.

- Phase I- Nutrient analysis of seeds and bark such as moisture, ash, fat, fiber, carbohydrate, protein.

- Phase II- Development of food products based on powder as an ingredient and sensory evaluation of products developed through 9- Point hedonic scale by trained and semi trained panels in the food lab.

- Phase III- Includes data analysis.

\section{PROXIMATE NUTRIENT COMPOSITION OF SEEDS AND BARK}

Moisture was estimated using hot air oven method and ash content Content by AOAC method (2000).

\section{Ash content}

About 5-10 g of the sample was weighed accurately into a tared platinum (or porcelain) crucible (which has previously been heated to about $600^{\circ} \mathrm{C}$ and cooled). The crucible was placed on a clay pipe triangle and heated first over a low flame till all the material was completely charred, followed by heating in a muffle furnace for about 3-5 hours at about $600^{\circ} \mathrm{C}$ then cooled in a desiccator and weighed. To ensure completion of ashing, the crucible was again heated in the muffle furnace for 1 hour, cooled and 
weighed. This was repeated till two consecutive weights were the same and the ash was almost white or grayish white in colour.

$$
\text { Ash content }(\mathrm{g} / 100 \mathrm{~g} \text { sample }) \quad=\frac{\text { Wt. of the ash }}{\text { Wt. of the sample taken }} \times 100
$$

\section{Crude fibre content}

About 2-5 g of moisture and fat-free sample was weighed into a $500 \mathrm{ml}$ beaker and $200 \mathrm{ml}$ of boiling $0.255 \mathrm{~N}(1.25 \% \mathrm{~W} / \mathrm{V})$ sulphuric acid was added. The mixture was boiled for $30 \mathrm{~min}$ keeping the volume constant by the addition of water at frequent intervals (a glass rod placed or kept in the beaker helps smooth boiling). At the end of this period, the mixture was filtered through a muslin cloth and the residue washed with hot water till free from acid. The material was then transferred to the same beaker, and 200 $\mathrm{ml}$ of boiling $0.313 \mathrm{~N}(1.25 \%) \mathrm{NaOH}$ was added. After boiling for $30 \mathrm{~min}$ (keeping the volume constant as before) the mixture was filtered through muslin cloth. The residue was washed with hot water till free from alkali, followed by washing with some alcohol and ether and then transferred to a crucible, dried overnight at $80-100^{\circ} \mathrm{C}$ and weighed (We). The crucible was heated in a muffle furnace at $600^{\circ} \mathrm{C}$ for 2 to 3 hours, cooled and weighed again (Wa). The difference in the weights (We-Wa) represents the weight of crude fibre.

$$
\left[100-\left(\text { moisture }^{*}+\text { fat }^{*}\right)\right] \times(\mathrm{We}-\mathrm{Wa})
$$

Crude fibre $\left(\mathrm{g} / 100 \mathrm{~g} \quad=\quad \frac{}{\text { Wt. of sample taken (moisture and fat free) }}\right.$

*g/100 g sample

\section{Fat content}

Fat was estimated as crude ether extract of the dry material. The dry sample (5-10 g) was weighed accurately into a thimble and plugged with cotton. The thimble was then placed in a Soxhlet apparatus and extracted with anhydrous ether for about 16 hours. The ether extract was filtered into a weighed conical flask. The flask containing the ether extract was washed 4 to 5 times with small quantities of ether and the washings were also transferred. The ether was then removed by evaporation and the flask with the residue dried in an oven at $80-100^{\circ} \mathrm{C}$, cooled in a desiccator and weighed.

Wt. of ether extract x 100

Fat content (g/100 g sample) =

Wt. of the sample (equivalent to fresh sample taken)

\section{Proteins}

Total proteins were estimated using macro-Kjeldahl method.
- Reagents used
a. Digestion mixture: 98 parts $\mathrm{K}_{2} \mathrm{SO}_{4}+2$ parts $\mathrm{CuSO}_{4}$
b. $40 \% \mathrm{NaOH}$
c. $\mathrm{N} / 10 \mathrm{NaOH}$ 
d. $\mathrm{N} / 10 \mathrm{H}_{2} \mathrm{SO}_{4}$

e. Methyl red indicator: $0.1 \mathrm{~g}$ of the indicator dissolved in $60 \mathrm{ml}$ of alcohol and water added to make to100 $\mathrm{ml}$.

\section{- Procedure}

The sample $(0.5-2.0 \mathrm{~g})$ was weighed into a dry Kjeldahl flask. About $5 \mathrm{~g}$ of digestion mixture and $20 \mathrm{ml}$ of pure conc. $\mathrm{H}_{2} \mathrm{SO}_{4}$ were added to the same sample and the mixture digested by heating for 4 to 5 hour. Glass beads were added to prevent bumping. After the contents of the flask become clear, the digestion was continued for at least 1 hour. The contents of the Kjeldahl flask were cooled, diluted with distilled water and the mixture was made alkaline by adding excess of $40 \% \mathrm{NaOH}$ (about $75 \mathrm{ml}$ ). A small quantity of pumice powder was added to prevent bumping during distillation. The ammonia liberated was distilled into a receiver containing $25 \mathrm{ml}$ of $\mathrm{N} / 10 \mathrm{H}_{2} \mathrm{SO}_{4}$. The excess of acid in the receiver was back titrated against N/10 NaOH using 3 drops of methyl red indicator. A reagent blank was similarly digested and distilled. This titre value was subtracted from the value obtained for the sample to get the true titre value ' $b$ '.

\section{- Calculation}

If ' $a$ ' $g$ of the sample is taken and if ' $b$ ' and ' $c$ ' $m l$ of alkali of normality ' $d$ ' are required for backtitration and to neutralise $25 \mathrm{ml}$ of $\mathrm{N} / 10 \mathrm{H}_{2} \mathrm{SO}_{4}$ respectively, then

The protein content in $\mathrm{g} / 100 \mathrm{~g}$ sample is $\quad(\mathrm{c}-\mathrm{b}) \times 14 \mathrm{~d} \times 6.25$

$$
\text { a } \times 1000
$$

\section{- Carbohydrate content}

The content of the available carbohydrate was determined by difference, i.e., by subtracting from 100 the sum of the values (per $100 \mathrm{~g}$ ) for moisture, protein, fat, ash and crude fibre.

\section{PREPARATION OF BAKERY PRODUCTS}

In present study two recipe (Biscuits and baked bites) were developed with variation (2\%, $4 \%$, $6 \%$ and $8 \%$ ) in each recipe there are standandard (S) and its variation were made by incorporation peach seed powdered and bark powdered. The product (Biscuits and baked bites) was made from Peach Seeds and Bark with four variants i.e. 2\%, 4\%, 6\% and 8\% proportion and then compared with the standard, then the sensory evaluation of prepared products were evaluated by 15 judges, selected randomly. For the sensory evaluation the following attribute were selected for hedonic rating test: Appearance, Colour, Flavour, Taste, Texture and Over all acceptability. The data obtained by sensory evaluation were quantified by calculating the mean, standard deviation of the scores.

\section{RESULT AND DISCUSSION}

\section{PROXIMATE COMPOSITION}

Table 1 showed that Peach Seeds contained 6.3\% moisture, 3.0\% ash, 36.9\% fat, 2.2\% protein, $1.3 \%$ fibre and $50.3 \%$ carbohydrate, respectively. However, they have higher values of Fat but 
low in Carbohydrate and Fibre. Whereas Bark contained low amount of Fat, Protein but were high in Carbohydrate according to Seed.

Table 1: Proximate Composition of Peach Seeds and Bark

\begin{tabular}{|l|l|l|l|l|l|l|}
\hline $\begin{array}{l}\text { Nutrients } \\
\text { (g/100g) } \\
\text { Samples }\end{array}$ & Moisture & Ash & Fat & Protein & Fibre & CHO \\
\hline Peach Seeds & $6.3 \pm 0.43^{\mathrm{ns}}$ & $3.0 \pm 0.16^{\mathrm{ns}}$ & $\begin{array}{l}36.9 \pm 0.16^{\mathrm{n}} \\
\mathrm{s}\end{array}$ & $2.2 \pm 0.26^{\mathrm{ns}}$ & $1.3 \pm 0.35^{\mathrm{ns}}$ & $50.3 \pm 0.04^{\mathrm{ns}}$ \\
\hline Peach Bark & $5.1 \pm 0.12^{\mathrm{ns}}$ & $4.7 \pm 0.40^{\mathrm{ns}}$ & $\begin{array}{l}29.2 \pm \\
0.26\end{array}$ & $1.0 \pm 0.09^{\mathrm{ns}}$ & $1.3 \pm 0.36^{\mathrm{ns}}$ & $58.7 \pm 0.16^{\mathrm{ns}}$ \\
\hline
\end{tabular}

Results are presented as mean \pm Standard deviation; values with different letters across the column are significantly different at $95 \%$ confidential level

\section{SENSORY EVALUATION}

\section{A. Biscuits (Fig 3 and Appendix-1)}

Data is reported as MEAN \pm SD group of fifteen panels each. All test recipes groups of Seed and bark (Std, 2\%, 4\%, 6\%, 8\%) compared to standard recipes (Fig 1 \& 2). Data revealed that Mean \pm SD for all the attributes (Appearance, Colour, Flavour, Taste, Texture and over all acceptability) lies between (5.0 $\pm 0.51-8.4 \pm 0.48)$. The result showed that variant Ist, $2 \mathrm{nd}$ and $3 \mathrm{rd}$ of Seed and Bark acceptable in comparison of variant 4th according to overall acceptability. The product also showed no significant difference ( $p>0.05$ ) compared to standard (Table 2 ).

Table 2: Acceptability Evaluation of Food Product Incorporated with peach Seeds and Bark Powder in Biscuits

\begin{tabular}{|c|c|c|c|c|c|c|c|c|c|c|}
\hline & \multicolumn{5}{|c|}{ Peach Seeds } & \multicolumn{5}{|c|}{ Peach Bark } \\
\hline Attributes & Std & $2 \%$ & $4 \%$ & $6 \%$ & $8 \%$ & Std & $2 \%$ & $4 \%$ & $6 \%$ & $8 \%$ \\
\hline $\begin{array}{l}\text { Appearanc } \\
\mathrm{e}\end{array}$ & $\begin{array}{l}8.0 \pm 0 \\
.49\end{array}$ & $\begin{array}{l}7.5 \pm 0 \\
.49\end{array}$ & $\begin{array}{l}6.9 \pm 0 \\
.57\end{array}$ & $\begin{array}{l}6.6 \pm 0 \\
.47\end{array}$ & $\begin{array}{l}6.0 \pm 0 \\
.99\end{array}$ & $\begin{array}{l}8.1 \pm 0 \\
.33\end{array}$ & $\begin{array}{l}7.6 \pm 0 \\
.48\end{array}$ & $\begin{array}{l}7.2 \pm 0 \\
.65\end{array}$ & $\begin{array}{l}6.8 \pm 0 \\
.54\end{array}$ & $\begin{array}{l}6.2 \pm 0 \\
.99\end{array}$ \\
\hline Colour & $\begin{array}{l}8.2 \pm 0 \\
.4\end{array}$ & $\begin{array}{l}7.5 \pm 0 \\
.49\end{array}$ & $\begin{array}{l}7.0 \pm 0 \\
.24\end{array}$ & $\begin{array}{l}6.9 \pm 0 \\
.67\end{array}$ & $\begin{array}{l}6.3 \pm 1 \\
.13\end{array}$ & $\begin{array}{l}8.2 \pm 0 \\
.44\end{array}$ & $\begin{array}{l}7.8 \pm 0 \\
.33\end{array}$ & $\begin{array}{l}7.4 \pm 0 \\
.49\end{array}$ & $\begin{array}{l}7 \pm \\
0.73\end{array}$ & $\begin{array}{l}6.5 \pm 1 \\
.14\end{array}$ \\
\hline Flavour & $\begin{array}{l}8.1 \pm 0 \\
.33\end{array}$ & $\begin{array}{l}7.4 \pm 0 \\
.48\end{array}$ & $\begin{array}{l}6.9 \pm 0 \\
.57\end{array}$ & $\begin{array}{l}6.4 \pm 0 \\
.71\end{array}$ & $\begin{array}{l}5.8 \pm 0 \\
.71\end{array}$ & $\begin{array}{l}8.0 \pm 0 \\
.24\end{array}$ & $\begin{array}{l}7.5 \pm 0 \\
.49\end{array}$ & $\begin{array}{l}7 \pm \\
0.63\end{array}$ & $\begin{array}{l}6.8 \pm 0 \\
.63\end{array}$ & $\begin{array}{l}6.1 \pm 0 \\
.88\end{array}$ \\
\hline
\end{tabular}




\begin{tabular}{|l|l|l|l|l|l|l|l|l|l|l|}
\hline Taste & $\begin{array}{l}8.0 \pm 0 \\
.24\end{array}$ & $\begin{array}{l}7.4 \pm 0 \\
.49\end{array}$ & $\begin{array}{l}6.8 \pm 0 \\
.54\end{array}$ & $\begin{array}{l}6.2 \pm 0 \\
.57\end{array}$ & $\begin{array}{l}5.1 \pm 0 \\
.61\end{array}$ & $\begin{array}{l}8.2 \pm 0 \\
.4\end{array}$ & $\begin{array}{l}7.6 \pm 0 \\
.48\end{array}$ & $\begin{array}{l}7.2 \pm 0 \\
.54\end{array}$ & $\begin{array}{l}6.4 \pm 0 \\
.61\end{array}$ & $\begin{array}{l}5.8 \pm 0 \\
.86\end{array}$ \\
\hline Texture & $\begin{array}{l}8.0 \pm 0 \\
.49\end{array}$ & $\begin{array}{l}7.1 \pm 0 \\
.49\end{array}$ & $\begin{array}{l}6.6 \pm 0 \\
.71\end{array}$ & $\begin{array}{l}5.8 \pm 0 \\
.74\end{array}$ & $\begin{array}{l}5 \pm 0.6 \\
3\end{array}$ & $\begin{array}{l}8.0 \pm 0 \\
.44\end{array}$ & $\begin{array}{l}7.4 \pm 0 \\
.61\end{array}$ & $\begin{array}{l}6.8 \pm 0 \\
.74\end{array}$ & $\begin{array}{l}6.1 \pm 0 \\
.61\end{array}$ & $\begin{array}{l}5.3 \pm 0 \\
.69\end{array}$ \\
\hline $\begin{array}{l}\text { Over all } \\
\text { acceptabilit } \\
\mathrm{y}\end{array}$ & $\begin{array}{l}8.3 \pm 0 \\
.47\end{array}$ & $\begin{array}{l}7.5 \pm 0 \\
.49^{\mathrm{ns}}\end{array}$ & $\begin{array}{l}6.8 \pm 6 \\
.8^{\mathrm{ns}}\end{array}$ & $\begin{array}{l}6.2 \pm 0 \\
.54^{\mathrm{ns}}\end{array}$ & $\begin{array}{l}5 \pm 0.5 \\
1^{\mathrm{ns}}\end{array}$ & $\begin{array}{l}8.4 \pm 0 \\
.48\end{array}$ & $\begin{array}{l}7.5 \pm 0 \\
.49^{\mathrm{ns}}\end{array}$ & $\begin{array}{l}7 \pm 0.6 \\
3^{\mathrm{ns}}\end{array}$ & $\begin{array}{l}6.4 \pm 0 \\
.61^{\mathrm{ns}}\end{array}$ & $\begin{array}{l}5.8 \pm 0 \\
.4^{\mathrm{ns}}\end{array}$ \\
\hline
\end{tabular}

Std $=$ standard, $a=$ significant difference, $n s=$ no- significance difference

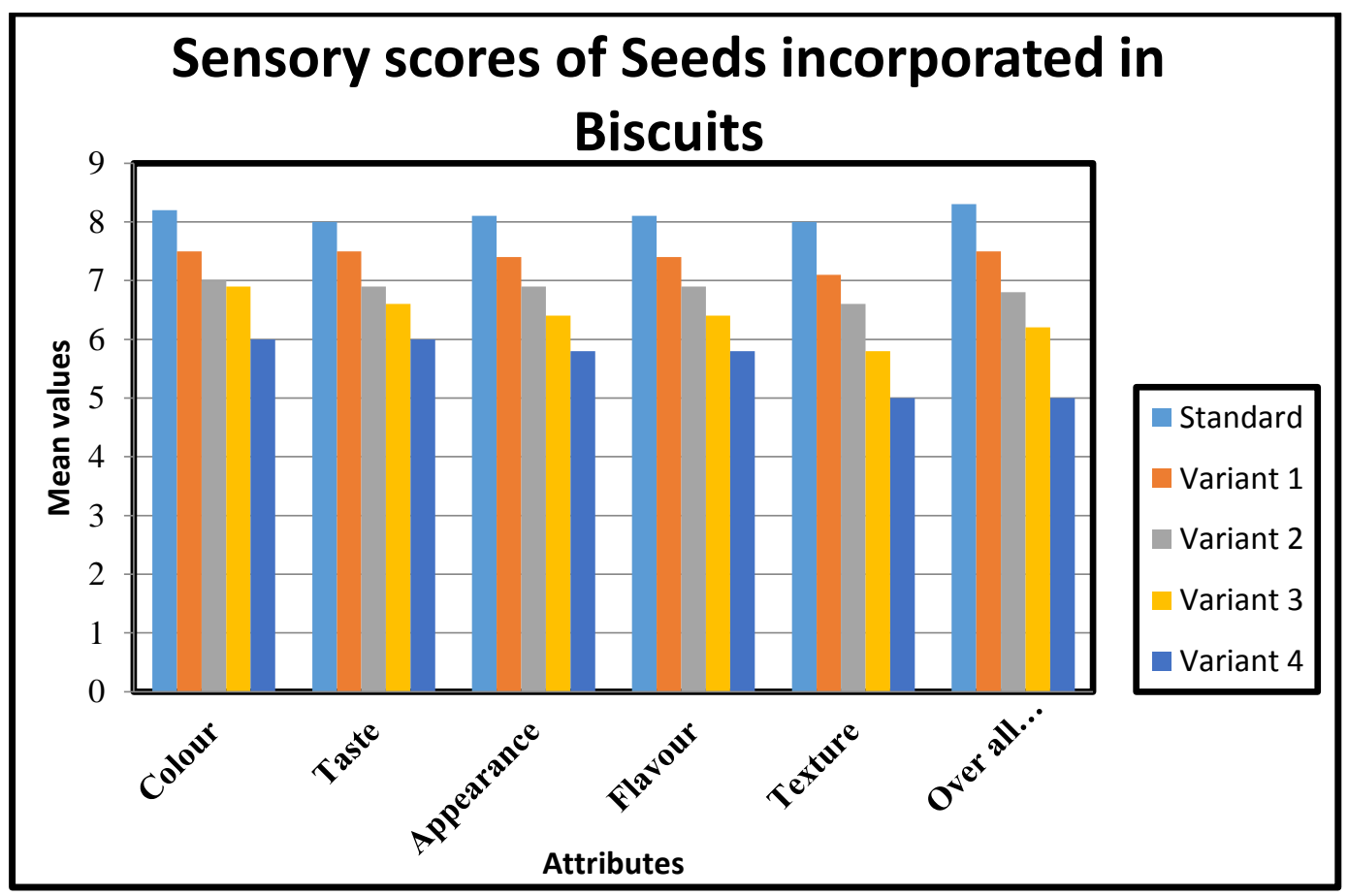

Figure 1: SENSORY EVALUATION DATA REPRESENTS SEED INCORPORATED IN BISCUITS 


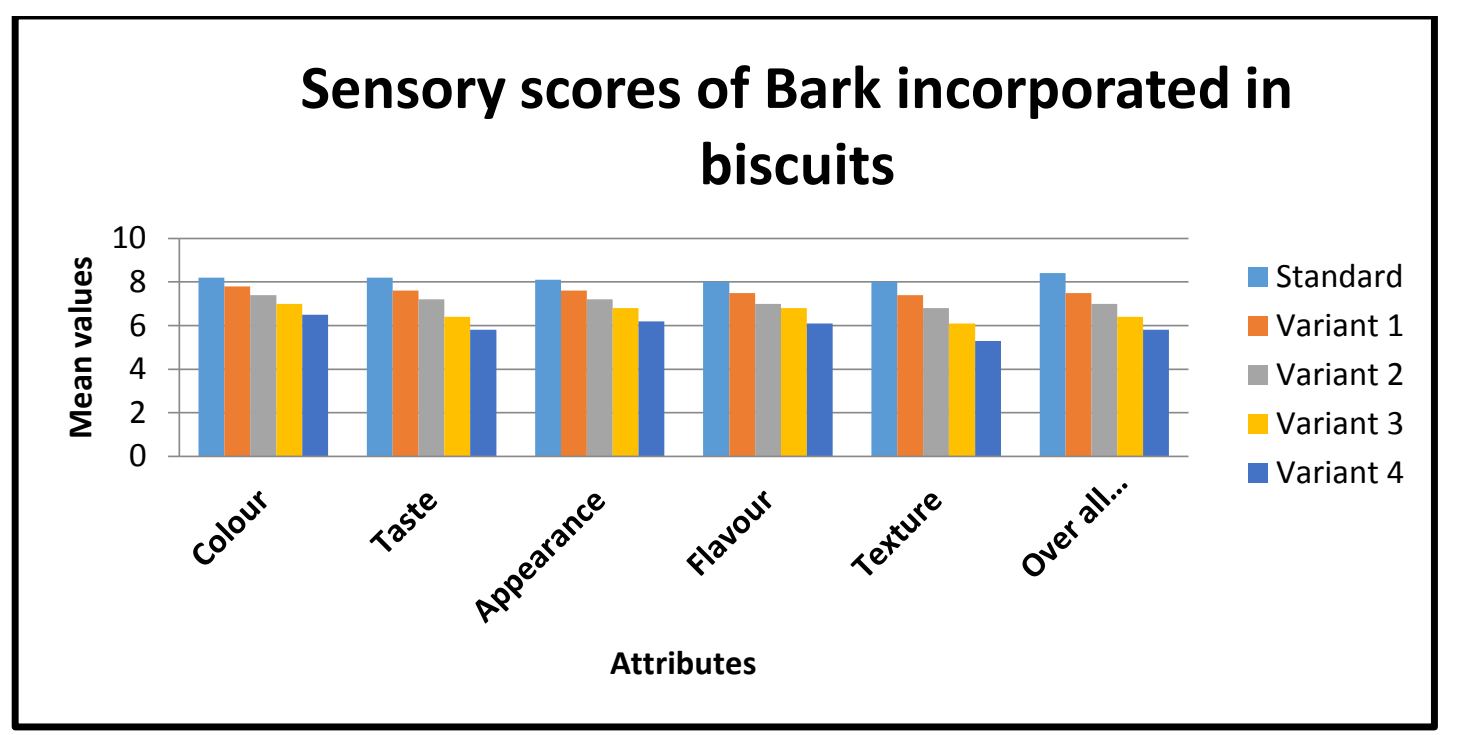

Figure 2: SENSORY EVALUATION DATA REPRESENTS BARK INCORPORATED IN BISCUITS

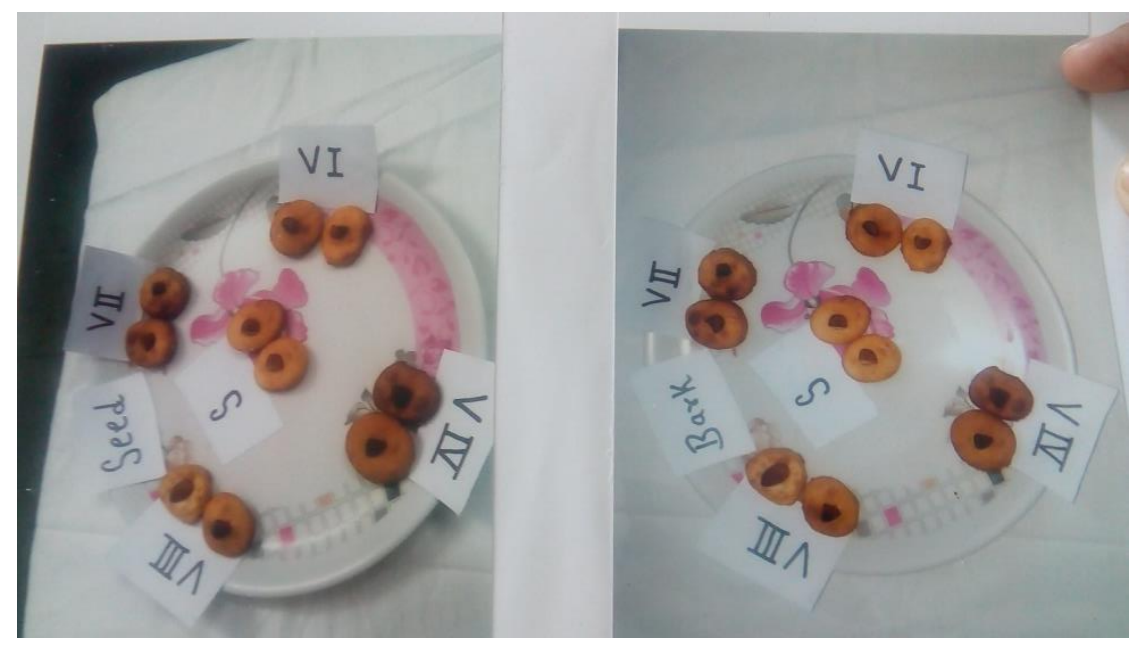

Figure 3:

B. BAKE BITE (Fig 6 and Appendix-2)

Table 3 revealed that Mean \pm SD for all the attributes (Appearance, Colour, Flavour, Taste, Texture and over all acceptability) lies between (5.6 $\pm 0.51-8.3 \pm 0.59)$. The result showed that variant $\mathrm{I}^{\text {st }}, 2^{\text {nd }}$ and $3^{\text {rd }}$ of Seed and Bark are more acceptable in comparison of variant $4^{\text {th }}$ according to overall acceptability. The product also showed no significant difference ( $\mathrm{p}>0.05)$ compared to standard (Fig $3 \& 4$ ).

Table 3: Acceptability Evaluation of Food Product Incorporated with peach Seeds and Bark Powder in Baked bite

\begin{tabular}{|l|l|l|l|l|l|l|l|l|l|l|}
\hline & \multicolumn{4}{|l|}{ Peach Seeds } & \multicolumn{3}{l|}{ Peach Bark } \\
\hline Attributes & Std & V1 & V2 & V3 & V4 & Std & V1 & V2 & V3 & V4 \\
\hline
\end{tabular}




\begin{tabular}{|c|c|c|c|c|c|c|c|c|c|c|}
\hline $\begin{array}{l}\text { Appearanc } \\
\mathrm{e}\end{array}$ & $\begin{array}{l}8.2 \pm 0 \\
.83\end{array}$ & $\begin{array}{l}7.4 \pm \\
0.48\end{array}$ & $\begin{array}{l}6.9 \pm 0 \\
.57\end{array}$ & $\begin{array}{l}6.7 \pm 0 \\
.57\end{array}$ & $\begin{array}{l}6.3 \pm 0 \\
.78\end{array}$ & $\begin{array}{l}8.1 \pm 0 \\
.61\end{array}$ & $\begin{array}{l}7.5 \pm 0 \\
.49\end{array}$ & $\begin{array}{l}6.9 \pm 0 \\
.57\end{array}$ & $\begin{array}{l}7.1 \pm 0 \\
.71\end{array}$ & $\begin{array}{l}6.6 \pm \\
0.1\end{array}$ \\
\hline Colour & $\begin{array}{l}8.0 \pm 0 \\
.25\end{array}$ & $\begin{array}{l}7.5 \pm \\
0.49\end{array}$ & $\begin{array}{l}7.0 \pm 0 \\
.53\end{array}$ & $\begin{array}{l}6.6 \pm 0 \\
.61\end{array}$ & $\begin{array}{l}6.2 \pm 1 \\
.13\end{array}$ & $\begin{array}{l}8.2 \pm 0 \\
.41\end{array}$ & $\begin{array}{l}7.8 \pm 0 \\
.34\end{array}$ & $\begin{array}{l}7.2 \pm 0 \\
.45\end{array}$ & $\begin{array}{l}6.9 \pm \\
0.70\end{array}$ & $\begin{array}{l}6.5 \pm \\
0.82\end{array}$ \\
\hline Flavour & $\begin{array}{l}8.3 \pm 0 \\
.59\end{array}$ & $\begin{array}{l}7.5 \pm \\
0.71\end{array}$ & $\begin{array}{l}7 \pm \\
0.73\end{array}$ & $\begin{array}{l}6.8 \pm 0 \\
.88\end{array}$ & $\begin{array}{l}6.4 \pm 0 \\
.95\end{array}$ & $\begin{array}{l}8.2 \pm 0 \\
.74\end{array}$ & $\begin{array}{l}7.8 \pm 0 \\
.54\end{array}$ & $\begin{array}{l}7.2 \pm \\
0.83\end{array}$ & $\begin{array}{l}7 \pm 0.0 \\
.81\end{array}$ & $\begin{array}{l}6.7 \pm \\
0.99\end{array}$ \\
\hline Taste & $\begin{array}{l}8.2 \pm 0 \\
.44\end{array}$ & $\begin{array}{l}7.6 \pm \\
0.48\end{array}$ & $\begin{array}{l}6.0 \pm 0 \\
.24\end{array}$ & $\begin{array}{l}6 \pm \\
0.63\end{array}$ & $\begin{array}{l}5.1 \pm 0 \\
.33\end{array}$ & $\begin{array}{l}8.2 \pm 0 \\
.4\end{array}$ & $\begin{array}{l}7.6 \pm 0 \\
.47\end{array}$ & $\begin{array}{l}7.1 \pm 0 \\
.49\end{array}$ & $\begin{array}{l}6.4 \pm 0 \\
.61\end{array}$ & $\begin{array}{l}5.6 \pm \\
0.47\end{array}$ \\
\hline Texture & $\begin{array}{l}8.1 \pm 0 \\
.71\end{array}$ & $\begin{array}{l}7.2 \pm \\
0.48\end{array}$ & $\begin{array}{l}7.0 \pm 0 \\
.24\end{array}$ & $\begin{array}{l}6 \pm \\
0.63\end{array}$ & $\begin{array}{l}5.6 \pm 0 \\
.71\end{array}$ & $\begin{array}{l}7.9 \pm 0 \\
.85\end{array}$ & $\begin{array}{l}7.6 \pm 0 \\
.61\end{array}$ & $\begin{array}{l}7 \pm 0.6 \\
3\end{array}$ & $\begin{array}{l}6.6 \pm 0 \\
.78\end{array}$ & $\begin{array}{l}5.9 \pm \\
0.69\end{array}$ \\
\hline $\begin{array}{l}\text { Over all } \\
\text { acceptabilit } \\
\mathrm{y}\end{array}$ & $\begin{array}{l}8.2 \pm 0 \\
.44\end{array}$ & $\begin{array}{l}7.5 \pm \\
0.61^{n} \\
s\end{array}$ & $\begin{array}{l}6.7 \pm 6 \\
.44^{\mathrm{ns}}\end{array}$ & $\begin{array}{l}6.2 \pm 0 \\
.54^{\mathrm{ns}}\end{array}$ & $\begin{array}{l}5 \pm 0.4 \\
4^{\text {ns }}\end{array}$ & $\begin{array}{l}8.3 \pm 0 \\
.47\end{array}$ & $\begin{array}{l}7.6 \pm 0 \\
.47^{\mathrm{ns}}\end{array}$ & $\begin{array}{l}6.9 \pm 0 \\
.44^{\mathrm{ns}}\end{array}$ & $\begin{array}{l}6.5 \pm 0 \\
.49^{\mathrm{ns}}\end{array}$ & $\begin{array}{l}5.6 \pm \\
0.48^{n} \\
s\end{array}$ \\
\hline
\end{tabular}

$\mathrm{a}=$ significant difference

ns= no- significance difference

\section{Sensory scores of Seed incorporated in Baked bite}

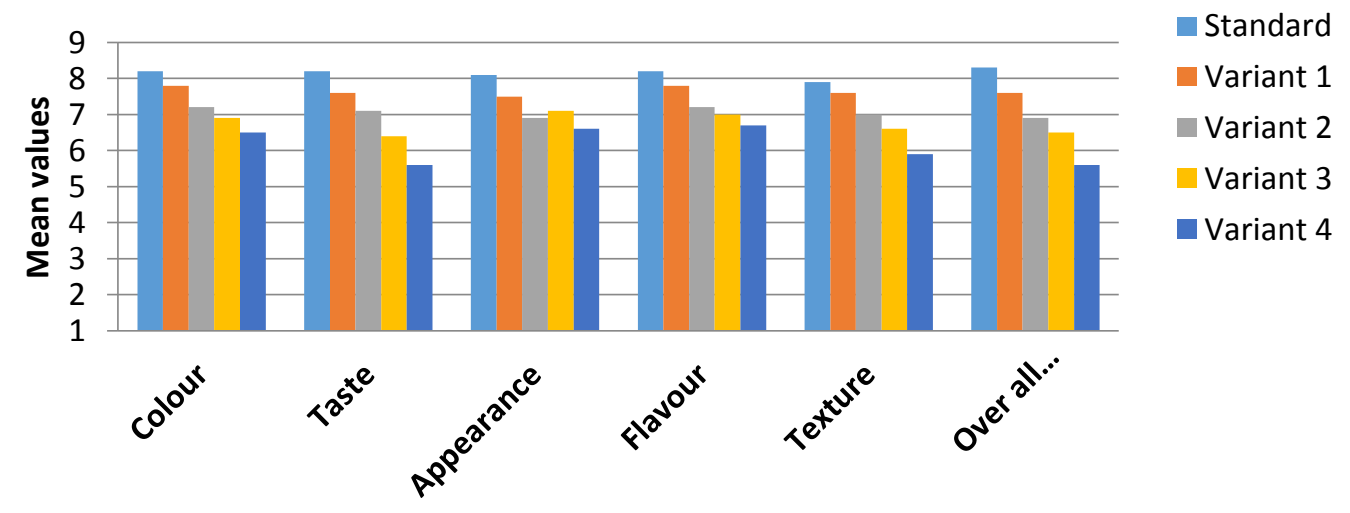

Attributes

Figure 3: Sensory Evaluation Data represented Seed Incorporated in Baked bite 


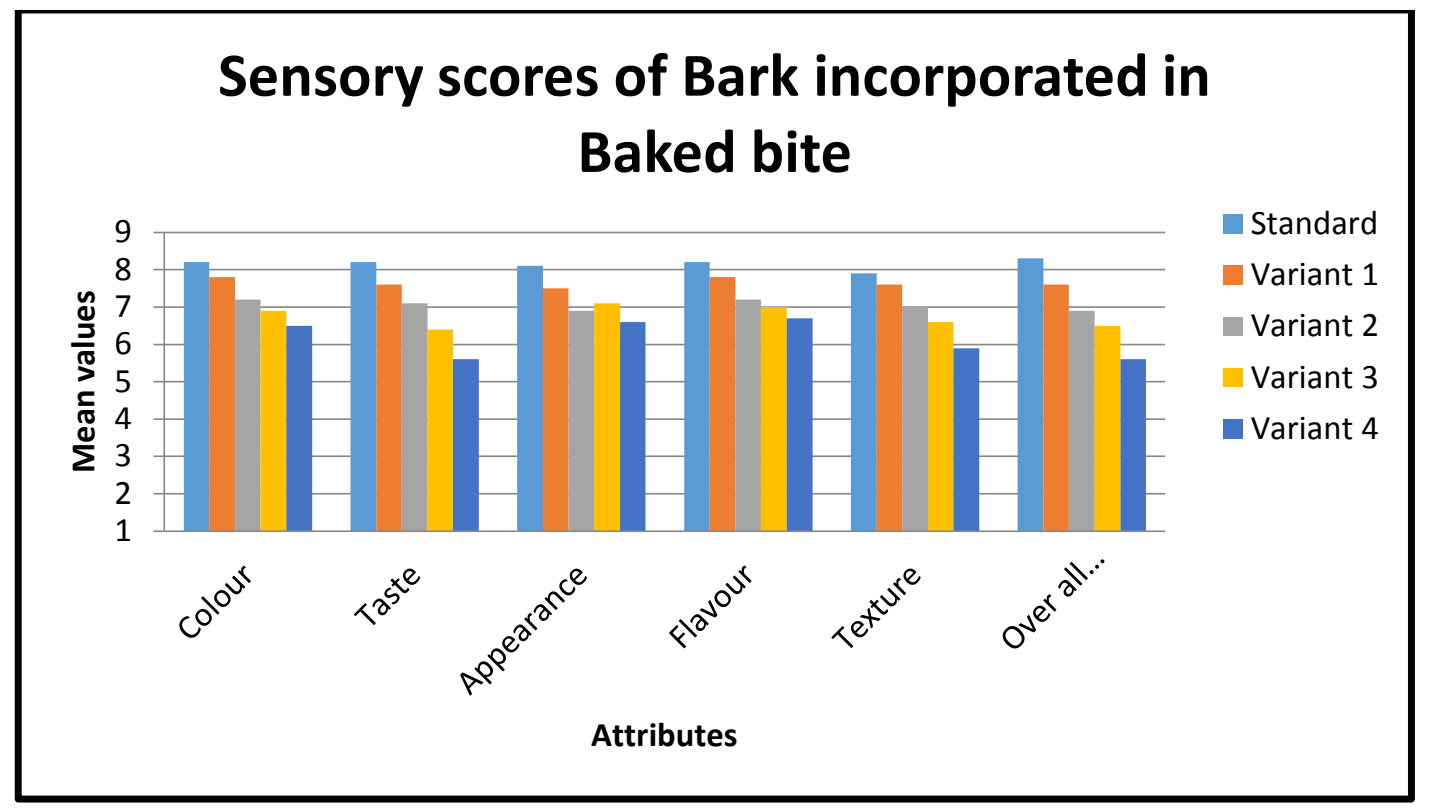

Figure 4: Sensory Evaluation Data represented Bark Incorporated in Baked bite

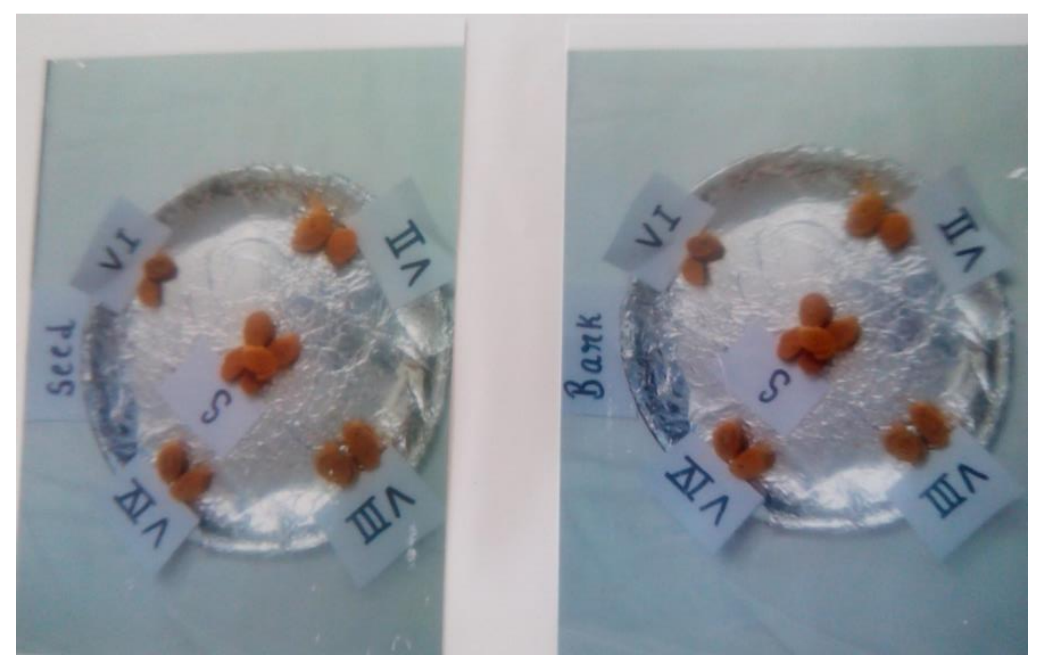

Figure 6:

\section{CONCLUSION}

Among the Plant species analyzed for evaluation of nutritional parameters of Prunus persica Seeds and Bark proved to have some nutritional parameters. The present study revealed that Seeds were good source of protein and thus could be potentially utilized as ingredient for animal or poultry food stuff. The Seeds of Prunus persica was high in fat in comparison to Bark but carbohydrate content was high in Bark, the carbohydrate of peach contains glucose, sucrose and fructose that are important energy resources. The result of sensory evaluation revealed that variant 1, 2 and 3 are more acceptable when compared with the standard. All the four variants showed no significant difference. 


\section{REFERENCES}

[1] Raturi R, Sati SC, Singh H, Bahuguna P and Badoni PP (2011) Chemical examination and anti-inflammatory activity of Prunus persica steam bark. International Journal of Pharmacy and Pharmaceutical Sciences, 3(5):315.

[2] Nastro A, Germanò MP, D'angelo V, Marino A, Cannatelli MA (2000) Extraction methods and bioautography for evaluation of medicinal plant antimicrobial activity. Lett Appl Microbiol, 30: 379-384.

[3] Raturi R, Sati SC, Singh H, Bahuguna P and Badoni PP (2011) Chemical examination and anti-inflammatory activity of Prunus persica steam bark. International Journal of Pharmacy and Pharmaceutical Sciences, 3(5):315.

[4] Anwar F, Manzoor M, Bukhari IH and Aladedunye F (2014) Physico-chemical attribute of fruit seed oils from different varieties of peach and pulm. Journal of Advances In Biology, 4 (2): 385.

[5] Aziz S and Rahman H (2013) Biological activities of prunus persica l. batch. Academic Journals, 7(15): 947.

[6] Aziz S and Rahman H (2013) Biological activities of prunus persica l. batch. Academic Journals, 7(15): 947.

[7] Kritikar KR and Basu BD (1984) Indian Medicinal Plants, Bishen Singh, Mahendra Pal Singh and Dehradun, 1:954.

[8] Backsheet EY, Faraq SF, Ahmen AS and Sayed HS (2003) Flavonoids and cyanogenic glycosides from the leaves and stem bark of prunus persica l. batch (meet ghamr) peach local cultivar in assiut region. Bull. Pharm. Sci., Assiut University, 26(1):55

[9] Deb L, Gupta R, Dutt A, Yadav A, Bhowmik D and Kumar KP (2013) Evaluation of antioxidant activity of aqueous fraction of Prunus persica L leaf aqueous extract. Pelagia Research Library, 1(3): 158.

[10] Shin C and Yogesh B (2010) Extraction of Active Compounds of Some Medical Plant. African journal of Biotechnology;9(21): 3210.

[11] Aziz S and Rahman H (2013) Biological activities of prunus persica l. batch. Academic Journals, 7(15): 947.

[12] Takenaga A., Ito S., Tsuyuki H. (1982) Nippon S and Kogyo G, 29, 724-729.

[13] Fujisaki M and Ishizawa K(1952) Symposia on Enzyme Chem., 7: 95.

[14] Baranwal A, Arora S, Kumar R, Praharsha J, Javed A and Sanobar N (2004) Evaluation of the combinational antimicrobial effect of prunus persica and annona squamosa seeds methanolic extract on standard microbial strains. Global Journal Of Bio-Sciences And Biotechnology, 2(4):517.

[15] Saddiq, AA. and Bawazir AE (2010) Antimicrobial activity of date palm (Phoenix dactylifera) pits extracts and its role in reducing the side effect of methyl prednisolone on some neurotransmitter content in the brain, hormone testosterone in adulthood. Acta Hort. (ISHS), 882: 665-690.

[16] Irobi ON, young $M$ and Anderson WA (1996) Antimicrobial activity of annatto (bixaorellana) extract .Int J Pharma, 38-90.

[17] Bauer AW, Kirby WM, Sherris JC and Turck M (1996) Antibiotic susceptibility testing by a standardize single disc method. Am J. Clin. Pathol. 45: 493-496.

[18] Rheder A (1940) Manual of cultivated trees and shrubs hardy in North America, Macmillan company, New York: 425-481. 


\section{APPENDIX -1}

\section{BISCUITS}

\section{INGREDIENTS}

Refined flour

Butter

Gram Flour (Besan)

Salt

Sugar

Vaniila essence

Almonds

\section{Amount}

$25 \mathrm{~g}$

$40 \mathrm{~g}$

$25 \mathrm{~g}$

$1 / 4$ tsp

$15 \mathrm{~g}$

4-5 drops

$10 \mathrm{~g}$

\section{PROCEDURE}

- First sieve the flours together.

- Then add salt to the flour.

- Mix well and add vanilla essence.

- Take butter (at the room temperature) add sugar to it and mix well until it becomes smooth.

- Now add the flour to the mixture and mix well until it becomes a soft dough.

- Preheat the oven to $375 \mathrm{~F}$.

- Now take a baking sheet and sprinkle some flour on it.

- Take small dough (small ball size) and make it like round and place it on the sheet continue the same procedure with the remaining dough and put nuts on it.

- Place the baking sheet in the oven and bake it for $10 \mathrm{~min}$.

\section{APPENDIX-2}

\section{BAKED BITES}

\section{INGREDIENTS}

Refined flour (maida)

Butter

Onion seeds (kalonji)

Salt

Red chilli powder

Chat msala
Amount
$250 \mathrm{~g}$
3tsp
$1 / 2$ tsp
to taste
to taste
to taste

\section{PROCEDURE}

- Mix all the ingredients together. Roll the dough.

- Roll the dough into two or three folds.

- Pre heat the oven to 375F.

- Now take a roll and put it in the oven and bake it for $20 \mathrm{~min}$. 